\title{
Design of Low-cost Automated Ventilator Using AMBU-bag
}

\author{
Hee-Bin Shin, Hyo-Kyeong Lee, Ga-Young $\mathrm{Oh}^{\dagger}$ \\ Department of Biomedical Engineering, Jeonbuk National University \\ 암부백을 이용한 저가형 자동 인공호흡기 설계 및 제작 \\ 신희빈, 이효경, 오가영 \\ 전북대학교 바이오메디컬공학부
}

\begin{abstract}
본 연구는 COVID-19의 대유행으로 인해 자동 인공 호흡기의 공급이 세계적인 긴급 수요에 비해 원활하지 않은 상황 에 도움이 될 수있는 저가형 응급 인공 호흡기의 설계 및 구현을 제안한다. AMBU-bag과 기성용 임베디드 마이크로 컨트롤러 보드를 사용하여 구현이 용이하고 비용을 최소화했다. 또한, $3 \mathrm{D}$ 프린팅은 전 세계 기업과 전문가들이 프로 토타입 하드웨어를 구축하는 데 사용하는 반면, 주변 환경에서 쉽게 구할 수 있는 재료는 많은 첨단 기술에 접근하기 어려운 국가의 사람들이 시스템을 제조할 수 있도록 한다. 설계한 간이 인공호흡기 모형의 특징은 암부 백을 자동화 했다는 점, $3 \mathrm{~d}$ 프린팅을 사용하지 않는다는 점, 속도조절이 가능하다는 점이다. 속도 조절이 가능하게 함으로써 사용 하는 환자의 상황에 맞게 환기가 가능하다. 연구 시 보완할 점으로는 첫 번째, 사용한 와이퍼 모터의 구동 시작점을 고 정하기 어렵다는 것이다. 이를 보완하기 위한 방법으로 위치 피드백기능이 있는 브러시 DC모터로 교체하는 방법이 있 다. 두 번째로 팔부분과 고정 틀이 나무 재질이라 암부 백을 장기적으로 압축하는 과정에서 암부백이 마모될 가능성 있다는 것이다. 이를 보완하기 위해 암부백이 닿는 틀과 팔 부분을 실리콘과 같은 재료로 감싸 마찰을 최소화해야 할 필요가 있다.
\end{abstract}

This study proposes the design and implementation of a low-cost emergency ventilator which can be helpful during the COVID-19 pandemic where the supply of automatic ventilators is not smooth compared with the urgent demand worldwide. Easy implementation and lower price were made possible by using AMBU-bag and off-the-shelf embedded microcontroller board. Moreover, while 3D printing is used by companies and experts around the world to build prototype hardware, materials which are readily available from surrounding environments so that people in countries where it is difficult to access many advanced technologies could manufacture the system. The design features AMBU-bag automation, not use 3D printing, and it can contrl speed. By allowing speed control, ventilation can be performed according to the conditions of the patient being used. A complementary point in the study is that it is difficult to fix the start point of the wiper motor used first. A method for complementing this is a method for replacing the brush DC motor with a position feedback function. Secondly, the AMBU-bag may wear out in the long-term process of compressing the AMBU-bag because the arm and the fixing frame are made of wood. To complement this, the part of fixing frame and arm parts that the AMBU-bag touches need to be wrapped in a material such as silicon to minimize friction.

KEYWORDS: BVM, COVID-19, Emergency, Respiration

\footnotetext{
${ }^{\dagger}$ To whom correspondence should be addressed.

E-mail: dhrkdud156@naver.com

Received: 30 May 2020, Revised: 04 March 2021,

Accepted: 26 May 2021
} 


\section{Introduction}

\section{1. 연구 배경}

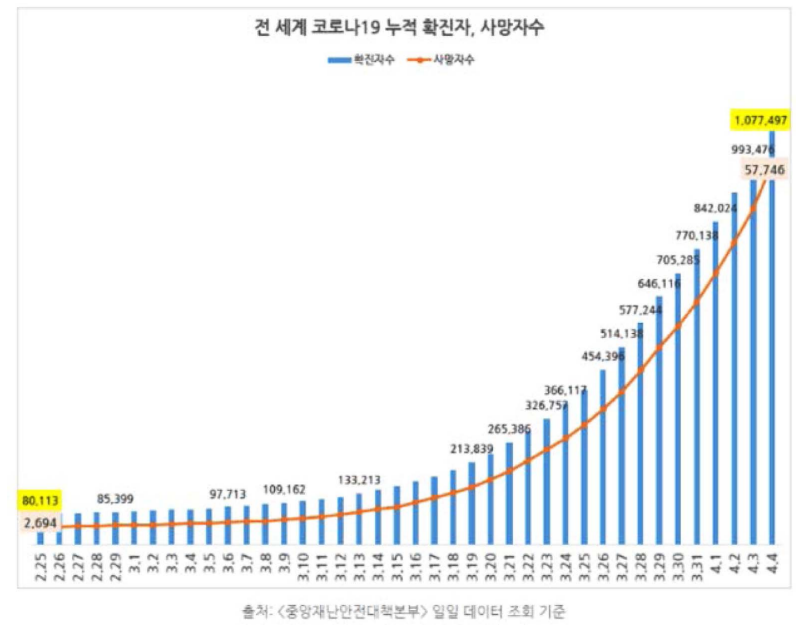

Figure 1. COVID-19 confirmed worldwide, death toll graph

지금 세계적으로 유행하고 있는 COVID-19는 폐에 손상 을 일으켜 신체의 산소 수준이 떨어지고 호흡이 어려워지 게 한다. 치료제가 없는 코로나의 사실상 '최후의 치료제' 역할은 인공호흡기이다. 그러나 기존의 인공호흡기는 비싼 비용과 복잡한 범용 기계 공급 부족 문제를 가지고 있다.

\section{최근 폭등한 독일 드레거 주가 (단위=유로)}

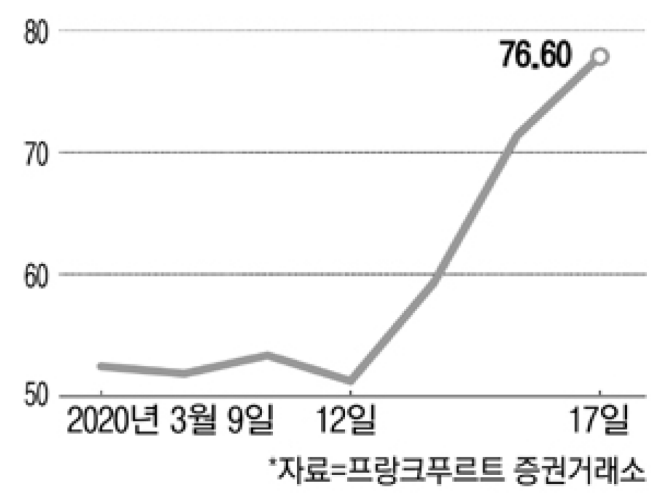

Figure 2. German respirator production company 'Drager' stock price graph

Figure 1은 코로나 바이러스의 초기 누적 확진자 수와 사 망자 수의 그래프이고, Figure 2는 독일 인공호흡기 생산회 사 드레거의 주가그래프이다. 두 그래프를 보면 코로나 바 이러스의 전 세계 확진자 수가 크게 증가함에 따라 인공호 흡기 생산회사의 주가 또한 급격히 증가하였음을 알 수 있다.

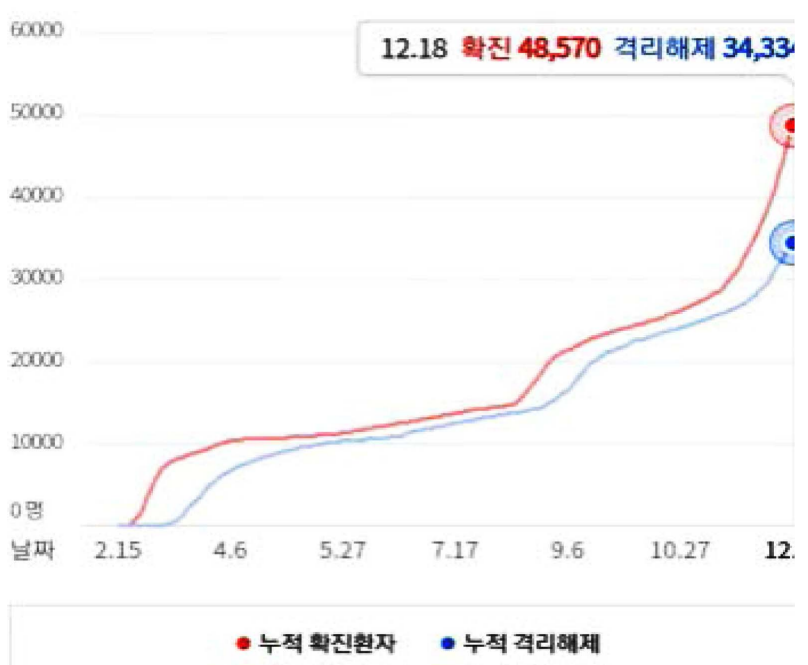

Figure 3. Cumulative confirmed cases in South Korea $\bullet$ release from quarantine

출처: 중앙재난안전대책본부, 중앙사고수습본부, 중앙방역대 책본부, Johns Hopkins CSSE

또한 Figure 3의 최근 누적확진환자와 격리해제 그래프를 보면 알 수 있듯이 우리나라도 확진자 수가 급격하게 늘면 서 인공호흡기나 $\mathrm{ECMO}$ 등의 치료가 필요한 위중증 환자 의 수는 Coronavirus Disease-19 (2020)의 코로나 발생 현황 발표에 따르면 2020년 12월 13일 179명과 비교해 12월 20 일에는 278명으로 급격히 늘고 있는 심각한 상황이다(Coronavirus Disease-19, 2020).

실제로 GlobalData(2020)에 따르면 '코로나바이러스 발생 으로 인해 전 세계적으로 약 88 만 개의 인공호흡기가 더 많 이 필요하다'고 계산하여 발표하였고 이를 해결하기 위해 이탈리아의 페라리와, 미국의 $\mathrm{GM}$ 과 포드, 독일의 $\mathrm{BMW}$, 영국의 롤스로이스 등 세계 각국의 자동차 업계와 미국 항 공우주국인 '나사'와 같은 여러 나라와 기업에서 인공호흡 기 생산에 뛰어들고 있다.

따라서 이 연구는 현 상황을 완화할 수 있는 암부백을 이 용한 자동화 저가형 인공호흡기 설계하고자 한다.

\section{2. 연구의 목적}

암부백을 이용한 자동화 저가형 인공호흡기 설계에 구체 적인 목적은 다음과 같다.

1. 적은 비용으로 간단하게 제작

2. 기성제품을 이용하여 제작

3. 수동소생기인 암부백을 자동화하는 방식 고안 


\section{Theory}

\section{1. 인공호흡기}

\section{1 인공호흡기 정의 및 목적}

인공호흡기는 호흡기 질환을 않고 있어 환자 스스로 적 절한 호흡을 할 수 없을 경우 호흡기능을 돕기 위해 설계 된 기계로, 풍부한 양의 산소를 환자의 폐로 직접 펌핑하거 나 환자의 체내에 쌓인 이산화탄소를 제거한다. 이러한 인 공호흡기는 동맥혈 산소화(oxygenation)의 개선, 호흡 일량 (work of breathing) 감소와 폐포 환기(alveolar ventilation) 조 절하는 생리학적인 목적이 있다. 또한 임상적인 목적은 급 성 호흡 산증과 저산소증을 호전시키고 호흡 곤란을 완화 시킴으로써 호흡으로 인한 호흡근의 부담이 감소하고 압력 -용적관계를 개선시킴으로써 폐의 순응도를 좋아지게 하며 폐 손상과 합병증을 예방하여 폐와 기도를 회복시키는 것 에 있다(KIm, 2019).

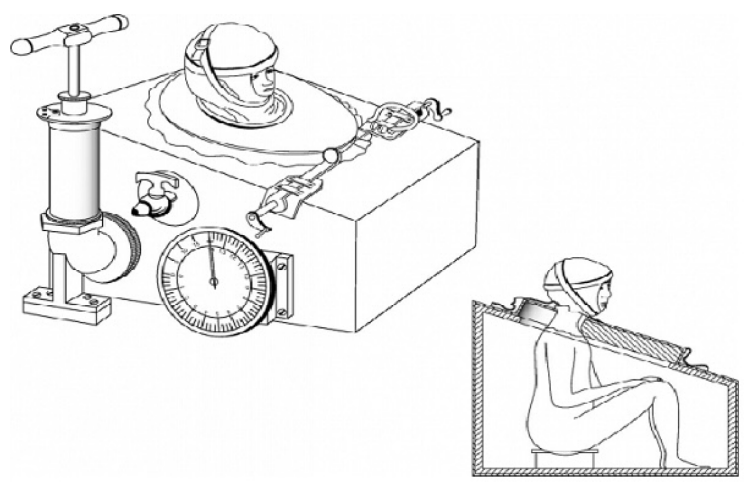

Figure 4. Alfred's first patented ironlung sketch in 1864

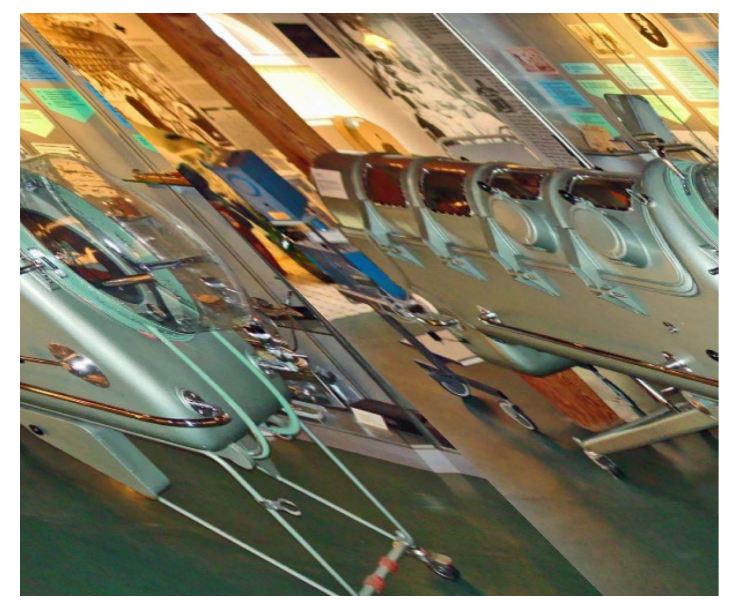

Figure 5. The early respirator iron Lung 출처: 위키피디아

\section{2 인공호흡기의 종류}

1) 음압 인공호흡기

음압 인공호흡기는 머리를 제외한 흥부나 몸 전제를 둘 러싸는 비 침습적 장치로 흥벽의 확장으로 흥강은 음압이 되고 압력 차이로 인해 공기가 흉강 내로 유입되는 방식이 다. 이러한 음압 인공호흡기의 종류로는 철폐(iron lung), 흥 갑(cuirass), 신체 덮개(body wrap) 등이 있다. 아래의 Figure 4와 Figure 5는 대표적인 음압 인공호흡기 철폐의 초기 스 케치와 모습이다.

\section{2) 양압 인공호흡기}

Figure 6은 병원에서 흔히 사용하는 양압 인공호흡기로 양 압 인공호흡기(CPAP)는 양압기 혹은 양압 지속 유지기로 불 리며 임상에서 주로 쓰이는 기계이며 수면 무호흡증 치료 혹은 코골이 치료 방법으로 널리 사용되고 있다. 흡기동안 양압의 공기를 폐 안으로 밀어 넣는 방식으로 침습적 양압 환기의 경우 기관 내 튜브를 삽관하거나 기관 절개 술이 필 요하다.

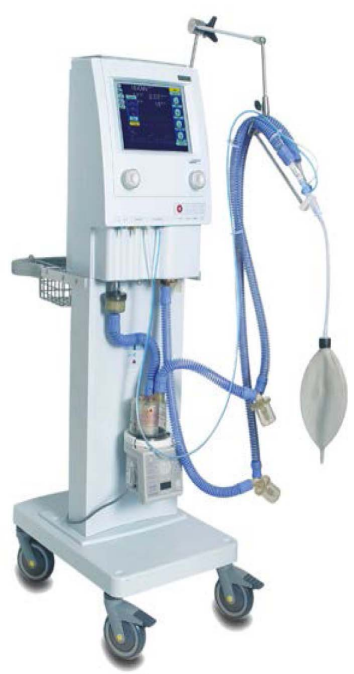

Figure 6. A general-purpose ventilator used in clinical trials 출처 : Hamiltion Medical AG

\section{3 환기 양식}

기계 환기를 위해선 여러 변수들을 고려해야하고 크게 제 어 변수에 따른 방식과 주기 변수에 따른 방식으로 분류된다.

\section{1) 조절변수(Control variable)}

조절 변수는 흡기 시작을 조절하기 위한 변수로 크게 압 력 조절 환기와 용적조절 환기로 분류할 수 있으며 Figure 7은 압력조절 환기와 용적 조절환기의 기본 파형이다. 


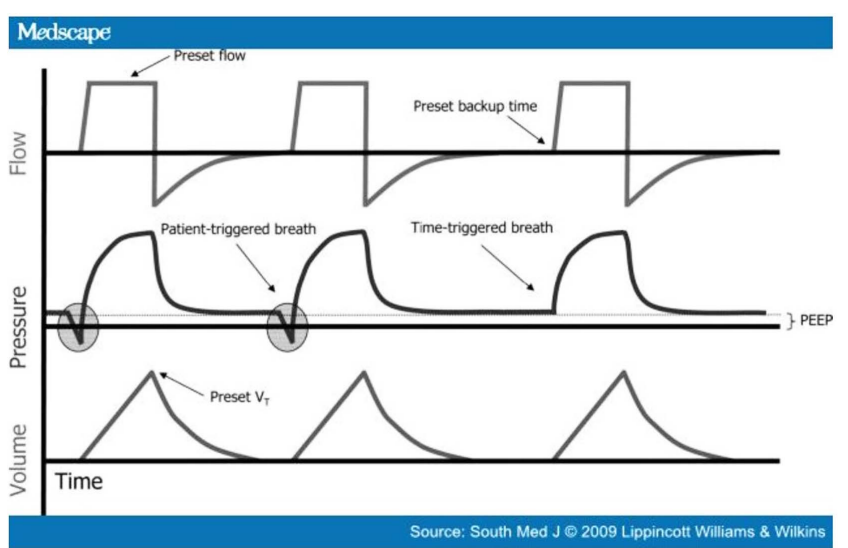

Figure 7. Default Waveform for Pressure control ventilation and Volume control ventilation

\section{가. 압력조절환기( $\mathrm{PVC})$}

압력조절환기는 일회 환기 시 설정된 압력의 기도 압을 일정하게 조절하여 환기가 이루어지는 양식이다. 동일한 기 도압에도 환자의 폐탄성과 기도저항에 따라 일회 호흡량이 변화한다. 또한 흡기압, 호흡수, 흡기시간 등 을 설정해 주 어야한다(Hong, 2012).

\section{나. 용적조절환기(VCV)}

용적조절환기는 일회 환기 시 설정된 용적을 목표로 공 기의 양을 일정하게 조절하여 환기가 이루어진다. $\mathrm{PCV}$ 와 달 리 환자의 기도저항이나 폐 탄성과는 무관하며 환자의 체 중에 맞게 일회호흡량을 정한다. 환기용적과 유량은 일정하 지만 압력은 폐의 역학에 따라 변화하며 용적조절환기는 호 흡수, 일회호흡량, 유량형태 등을 설정해 주어야한다(Hong, 2012).

\section{2) 위상변수(Phase variable)}

위상변수는 호흡주기를 결정하는 환기의 위상을 조절하 는 변수로 유발(trigger), 제한(limit), 주기(cycle)가 있다.

호기에서 흡기로 전환되는 것을 결정하는 변수가 유발 변 수이며 흡기가 지속되는 동안 변화를 제한하는 것이 제한 변수이다. 또한 지속되던 흡기가 끝나고 호기로 전환을 결 정하는 변수는 주기 변수이다(Park, 2018).

\section{3) 환기유형}

가. 강제 조절환기 $(\mathrm{CMV})$

$\mathrm{CMV}$ 는 자발적으로 호흡할 수 없는 환자에게 적용하며 대 상자의 호흡은 정해진 설정에 따라 인공호흡기에 의해 이 루어지며 $\mathrm{CVC}$ 와 $\mathrm{PVC}$ 로 나뉘게 된다. 또한 일회호흡량과 호흡수를 환자의 상태와 관계없이 무조건 기도로 전달이 되
어 호흡시작능력이 있는 환자는 기계와 충돌하여 손상을 입 을 수가 있기 때문에 환자를 마취시켜 자발호흡을 억제해 야 한다.

\section{나. 보조/조절 환기양식(A/C)}

$\mathrm{A} / \mathrm{C}$ 는 환자의 흡기 노력을 감지하여 호흡 촉발을 시작하 며 정해진 일회호흡량이나 기도압에 도달하도록 보조하고 설정된 호흡수 이하가 될 경우 조절 환기로 전환되는 방식 이다. 또한 민감도의 설정에 따라 호흡량이 달라지며 민감 도가 낮을 경우 자발호흡 노력이 높아야 기계가 도와 호흡 량을 전달하지만 민감도가 높을 경우 미약한 숨에도 자발 호흡으로 간주하여 보다 많은 호흡수가 촉발된다(Son, 2012).

\section{다. 동시간헐적강제환기(SIMV)}

SIMV는 환자의 자발적 호흡이 가능하여 환자의 호흡과 간헐적 기계호흡의 충돌을 보완하기 위해 기계호흡을 환자 의 호흡노력에 맞춰 동시에 시작하도록 하는 양식으로 기 계호흡과 자발호흡이 함께 이루어져 환자는 더 편하게 기 계호흡을 전달받게 되고 인공호흡기에 대한 의존도를 낮추 고 자발호흡을 늘리게 한다. 하지만 호흡 노력이 설정된 시 간 안에 감지되지 않을 경우 강제 호흡이 주어진다(Son, 2012).

\section{라. 지속적 양압환기(CPAP)}

설정된 기도 내 양압을 유지하여 공기가 쉽게 폐로 들어 갈 수 있게 하여 환자의 자발적인 호흡이 이루어질 수 있 게 돕는다. 하지만 호흡수는 오직 환자의 자발호흡에 의해 결정이 되고 주로 인공호흡기를 제거하기 직전에 이용되는 양식이다.

\section{Materials and Methods}

\section{1. 재료}

작품을 만드는데 에 사용한 주재료로 성인용 사이즈의 암 부백, 고정 대와 팔 부분을 만들기 위한 책꽂이, 브러시 DC 모터, 아두이노 우노, 모터 드라이버 모듈, 리드스크류를 사 용하였고. 작품을 만드는데 필요한 금액은 약 19 만 원 정도 들었다.

\section{1 암부백(AMBU-bag)}

Figure 8의 암부백은 호흡 정지 시에 사용하는 구급 소생 백이다. 호흡이 원활하지 않거나 호흡이 적당하지 않은 환 자에게 양압 환기를 제공하기 위해 일반적으로 사용되는 휴 대용 장치이다. 


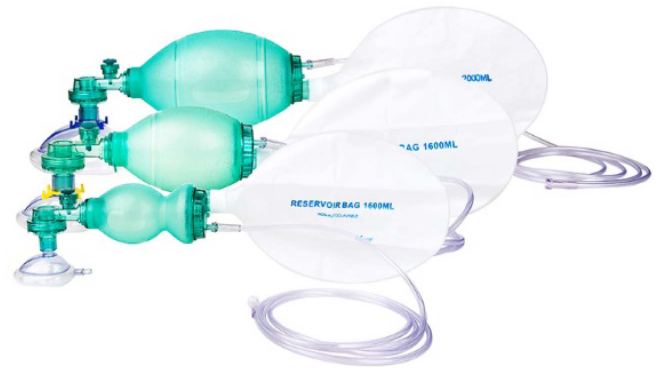

Figure 8. AMBU-bag 출처: GaleMed

암부백은 환자에게 호흡가스를 효과적으로 전달하는 마 스크와 호흡가스가 전달되고 숨이 배출되게 하는 환자밸브, 압력을 조절하는 압력 조절 밸브, 호흡낭(bag), 호흡가스를 제공 및 차단 역할을 하는 흡기밸브, 그리고 산소가 임시적 으로 저장되는 공간인 산소 저장 백으로 이루어져 있다.

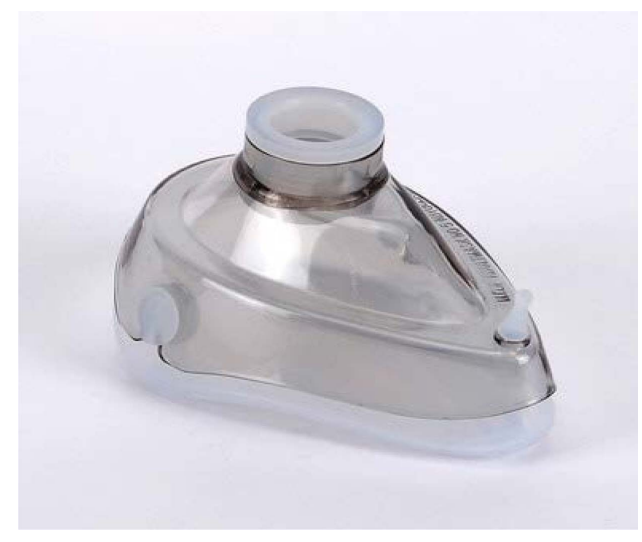

Figure 9. Mask

출처: 메디카페

Figure 9는 암부백 마스크 모습으로 마스크가 올바르게 착 용되고 백이 압착되면 장치는 환자의 폐로 공기를 통과시 키고, 백이 풀리면 반대쪽 끝에서 자체 팽창하여 주위 공기 나 조절된 실린더에서 공급되는 저압 산소 흐름을 끌어내 는 동시에 환자의 폐가 일방통행 밸브를 지나 주변 환경으 로 수축하도록 한다(Ha et al., 2006).

백과 밸브는 마스크 대신 대체기도 부속물에 부착 할 수 도 있다. 예를 들어 기관 내 튜브나 후두 마스크 기도에 부 착할 수 있고 소형 열 및 습도 교환기 또는 Figure 10와 Figure 11의 박테리아 필터와 수소 성 필터를 사용할 수도 있다.

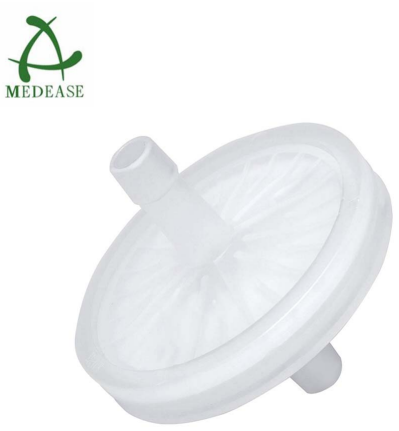

Figure 10. Bacteria/Virus filter 출처: MEDEASE LIFE CO., LTD

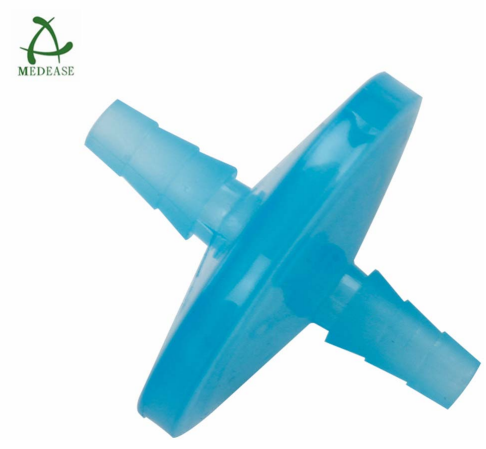

Figure 11. Hydrophobic filter 출처: MEDEASE LIFE CO.,LTD

Figure 10은 박테리아/바이러스 필터로 암부백에 장착한 다면 세균 여과 효율 : 최대 $99.99 \%$, 바이러스 여과 효율: 최대 $99.97 \%$ 의 효과를 볼 수 있고 호흡기의 2차적 교차 감 염을 예방 할 수 있다. Figure 11는 수소 성 필터(hydrophobic filter)로 Korean Society of Anesthesiologists (2020)에서는 COVID-19 의심 환자에 대한 마취 관리 지침으로 '수술전 후 환자 이송 중 공기가 오염되지 않게 소수성 필터 (hydrophobic filter)를 사용해야 한다.'라고 했다(Korean Society of Anesthesiologists (KSA), 2020).

암부백을 사용하기 전 주의사항으로는 사용 전 입구를 막 고 백을 수축해 공기가 새지 않는지 확인하여야 한다. 입구 를 막은 상태에서 사용 시에 공기가 새지 않아야 하고 백 이 잘 눌리지 않아야 한다.

또한 과도한 힘을 가해 사용할 경우 플라스틱 부분과 고 무가 찢어질 수 있기 때문에 조심하여야 한다. 성인의 폐활 량은 약 $500 \mathrm{CC}$ 이므로 앰브 용적을 다 사용하면 지나치게 호흡을 하게 되어 과한기가 올 수 있기 때문에 조금씩 수 축하여 사용해야 한다. 과한 기시에는 뇌의 혈관이 수축하 여 뇌혈류량 감소를 유발할 수도 있다.

암부백을 관리할 시에는 환자 당 하나의 암부백을 사용 
하고 여러 명의 환자가 사용하지 않도록 해야 한다. 또한 병 원 내규에 따라서 주기적으로 암부백을 교체하고 사용 후, 사용하지 않을 때에는 반드시 소독을 하여야 한다.

\section{2 모터}

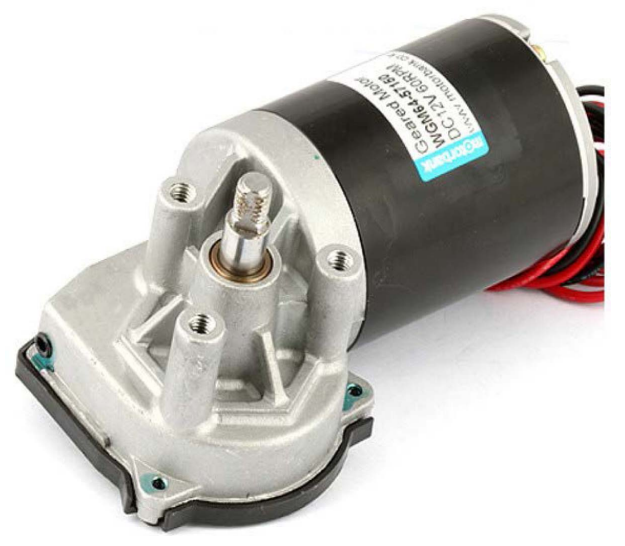

Figure 12. Wiper motor

모터 같은 경우에는 각도 감지 기능이 통합되어 있거나 분리된 충분히 높은 토크의 역 구동 모터여야 하기 때문에 Figure 12 와 같은 주변에서 쉽게 구할 수 있는 와이퍼 모터 를 사용했다. 스프링 커플링을 이용하여 모터와 리드스크류 를 연결시켜 팔부분이 동작할 수 있도록 했다.

\section{3 모터 드라이버 모듈}

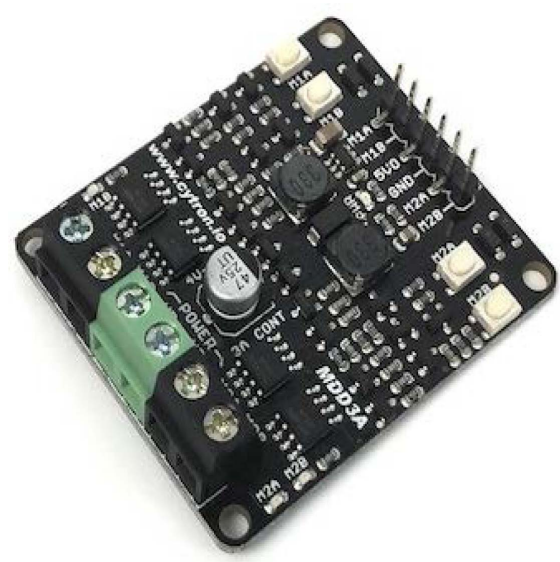

Figure 13. Motor driver module 출처: 메카솔루션

사용한 Figure 13의 모터 드라이버 모듈은 $4 \mathrm{~V} \sim 16 \mathrm{~V}$ 에 해 당하는 DC 모터의 방향을 바꿀 수 있고 속도를 제어할 수 있으며, 모터 당 $3 \mathrm{~A}$ 의 연속 전류를 허용한다. 아두이노와 같
이 $3.3 \mathrm{~V} \sim 5 \mathrm{~V}$ 로직의 마이크로 컨트롤러와 함께 사용할 수 있으며, PWM 신호와 디지털 신호를 통해 모터를 제어한 다. 또한 모터의 동작을 테스트 해볼 수 있다.

\section{4 고정틀}

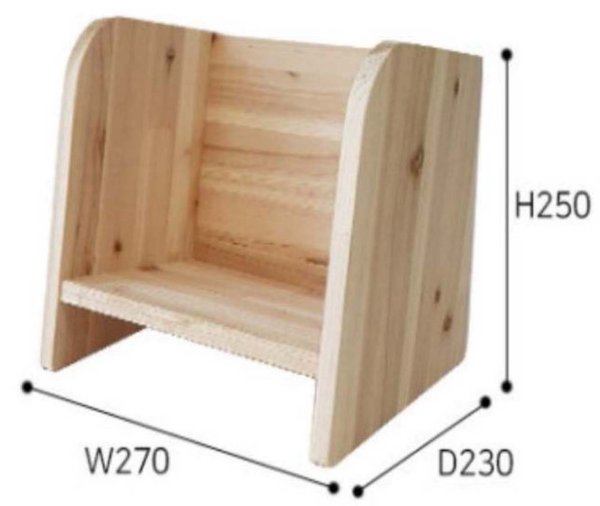

Figure 14. Bookshelf

암부백을 고정시켜 압축할 수 있도록 하는 틀로는 Figure 14 과 같은 책꽂이를 사용했다. $3 \mathrm{D}$ 프린터를 활용하여 틀을 만들 수 있지만 이 프로젝트의 목적에 따라 기성품을 사용 하는 방법을 택했다.

성인용 암부백의 사이즈는 $255 \mathrm{~mm}$ 정도이며 밸브를 포 함한 총 길이는 $300 \mathrm{~mm}$ 정도의 길이이므로 암부백의 사이 즈보다 작은 사이즈의 책꽃이를 사용해 책꽂이 양쪽 면에 압 력 조절밸브와 흡기밸브가 통과할 수 있을만한 사이즈의 구 멍을 뚫어 통과시킨 뒤 암부백을 고정시킬 수 있도록 했다.

\subsection{Arm}

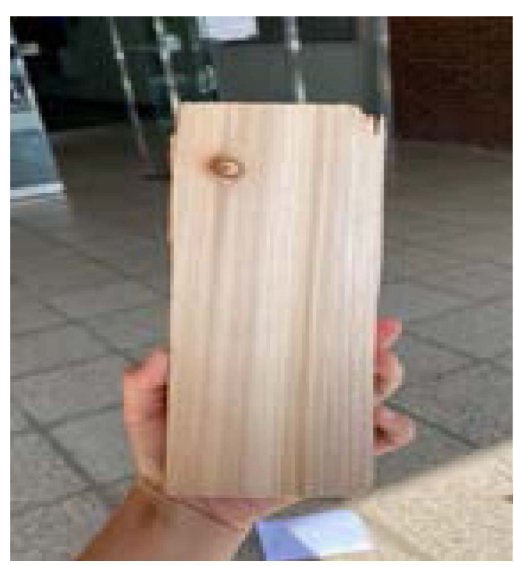

Figure 15. 'Arm' made using the back of the bookshelf

암부백을 압축하는 팔 부분은 Figure 15 과 같이 책꽂이 뒷 
면의 필요 없는 부분을 잘라 만들었다. 압축을 반복할수록 암부백이 마모될 수 있으므로 암부백에 직접 밀착이 되는 부분은 갈아내어 다듬어 주었다.

\section{2. 간이 인공호흡기 제작 과정}

\section{1 제작 모형도}

모터 사용과 고정 틀에 따라 4가지 모형도를 그렸다.

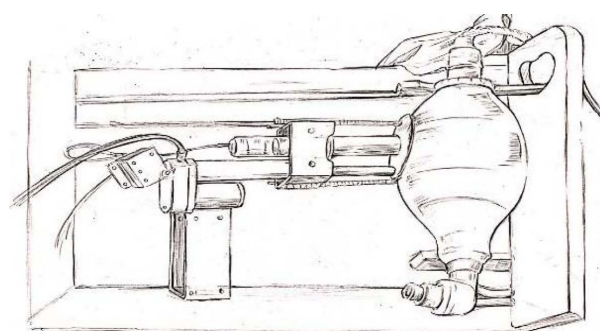

Figure 16. Model sketch 1

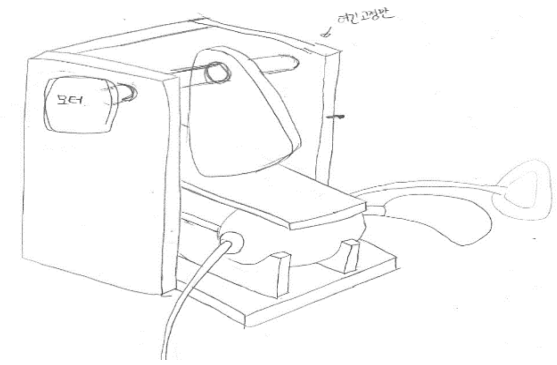

Figure 17. Model sketch 2

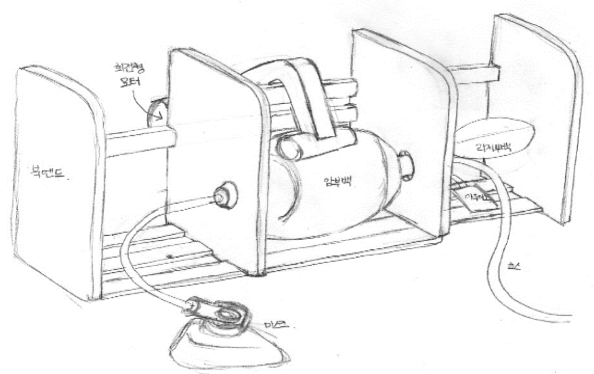

Figure 18. Model sketch 3

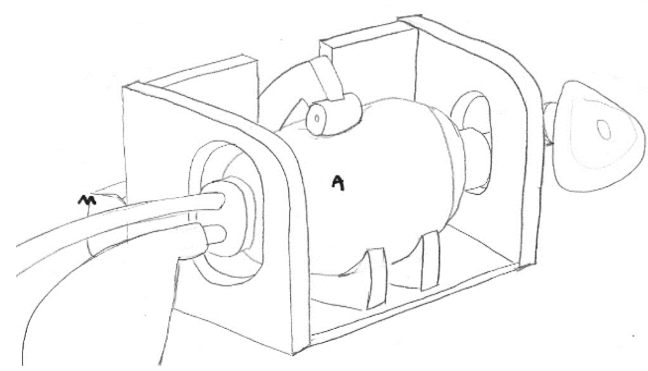

Figure 19. Model sketch 4
Figure 16는 리니어모터를 사용하여 암부백을 벽에 고정시 키고 피스톤 질하여 암부백을 압축하는 방식이다. Figure 17 은 양쪽길이가 다른 판을 360 도 회전시켜 암부백을 압축하 는 방식이다. Figure 18과 Figure 19은 DC모터를 사용하여 지정한 각도만큼 회전을 반복시켜 암부백을 압축하는 방식 으로, 고정 틀에 차이를 두었다. 이중 제작모형도4를 바탕 으로 제작했다.

\subsection{D 제작}

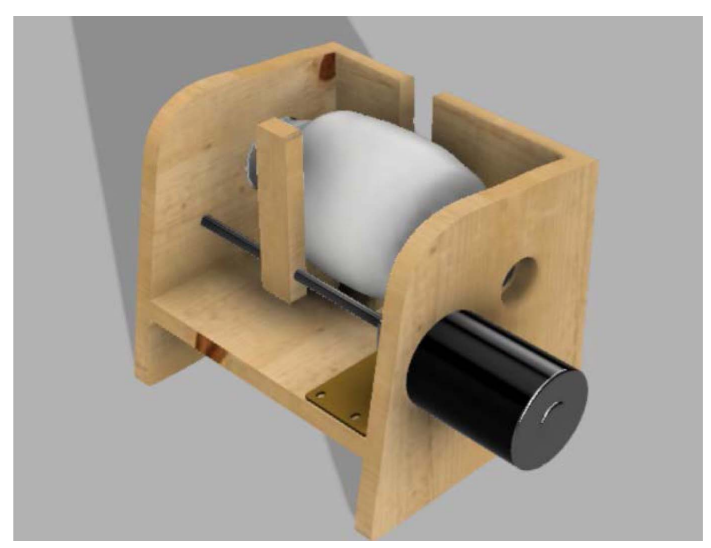

Figure 20. 3D model

Figure 20은 4번 모형도를 바탕으로 Fusion 360을 이용해 3D 모형을 제작했다. 최대한 적은 비용을 사용하기 위해 고정 틀의 필요 없는 부분을 이용하여 팔 부분을 제작했다.

\section{3. 시스템}

\subsection{Arduino}

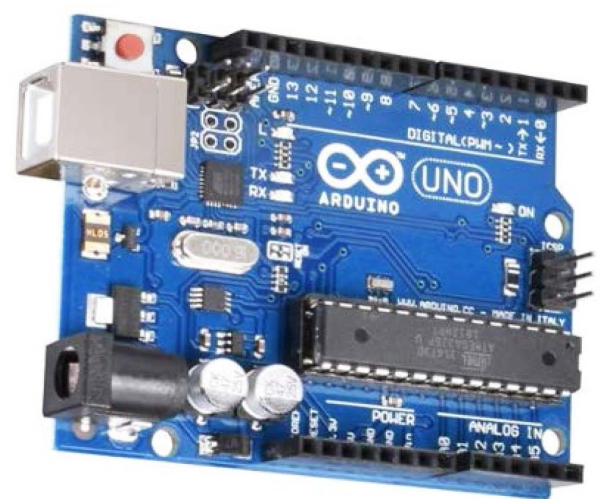

Figure 21. Arduino Uno 출처: 네이버 
$\mathrm{DC}$ 모터의 속도를 제어할 수 있고 방향을 바꿀 수 있는 모터 드라이버 모듈과 Figure 21와 같이 아두이노 우노를 사 용하여 전원버튼과 속도버튼을 만들었고 속도조절 버튼을 누르면 세단계로 조절 가능하도록 만들었다.

\section{4. 제작한 간이 인공호흡기 설명}

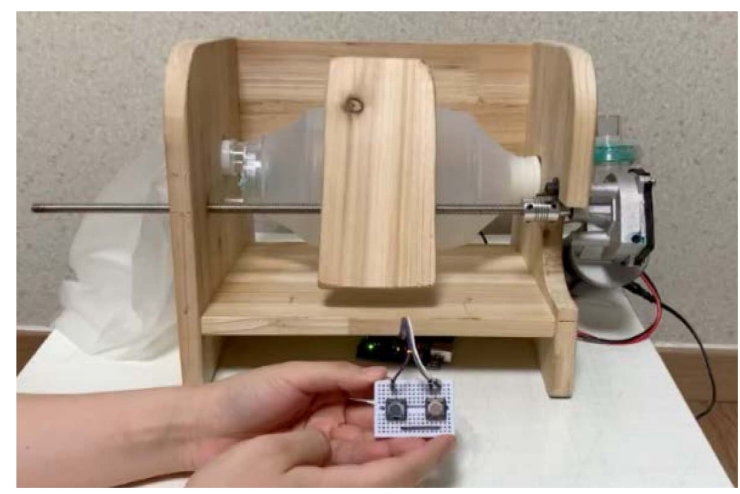

Figure 22. Complete Ventilator Model

Figure 22에서 보는 바와 같이 사람 손으로 고정하고 있 어야 하는 불편함을 해소하기 위해 주위에서 쉽게 구할 수 있는 책꽂이에 적절한 구멍을 뚫어 암부백을 고정시켰다. 또 한 백을 눌러줄 수 있는 Arm 부분도 책꽂이의 일부분을 잘 라내어 이용했으며 환자에 따라 조절하기 위한 컨트롤러는 책꽂이 아래 공간에 넣어둘 수 있다.

\section{Results and Discussion}

본 연구에서는 수동형 암부백을 자동화시킴으로써 의료 진이 직접 암부백을 누르지 않아 의료진의 인력 부족 문제 를 해소하고, 전 세계 기업과 전문가들이 $3 \mathrm{~d}$ 프린팅을 이용 해 제작을 하는데 반해 비싼 인공호흡기를 구하기 어려운 국가나 지역에도 도움이 될 수 있도록 쉽게 구할 수 있는 재료를 사용하고 고도의 기술력이 없어도 제작이 가능하게 끔 하는 것에 초점을 두었다.

설계한 간이 인공호흡기 모형의 특징은 암부백을 자동화 했다는 점, $3 \mathrm{~d}$ 프린팅을 사용하지 않는다는 점, 속도조절이 가능하다는 점이다. 속도 조절이 가능하게 함으로써 사용하 는 환자의 상황에 맞게 환기가 가능하다.
연구 시 보완할 점으로는 첫 번째, 사용한 와이퍼 모터의 구동 시작점을 고정하기 어렵다는 것이다. 이를 보완하기 위 한 방법으로 위치 피드백기능이 있는 브러시 DC모터로 교 체하는 방법이 있다. 두 번째로 팔부분과 고정 틀이 나무 재 질이라 암부백을 장기적으로 압축하는 과정에서 암부백이 마모될 가능성 있다는 것이다. 이를 보완하기 위해 암부백 이 닿는 틀과 팔 부분을 실리콘과 같은 재료로 감싸 마찰 을 최소화해야 할 필요가 있다.

추후 실제로 기능이 가능하도록 압력 감지기와 유량 감 지기를 추가하는 연구를 진행하고, 소프트웨어를 보완한다 면 간이 인공호흡기의 기능을 온전히 할 수 있을 것으로 보 인다. 또한 영국의 보건의료제도 NHS(National Health Service) 의 응급 인공호흡기 요구사항에 만족하기 위해 고 장 감지를 위한 압력 감지기 경보 및 고장 발생 시 경보를 생성하는 버저 추가와, LED- 압력 및 기타 값을 표시하는 $\mathrm{LCD}$ 화면 설정기능을 추가한다면 NHS의 요구사항을 충족 시킬 수 있을 것이다.

\section{References}

Coronavirus Disease-19, Republic of Korea. (2020). Cases in Korea, http://ncov.mohw.go.kr/bdBoardList_Real.do?brdId=1\&brdGubun $=11 \&$ ncvContSeq $=\&$ contSeq $=$ \&board_id=\&gubun

Ha, K. S., Moon, I. H., Lee, H. S., Dong, H. S., So, H. E., Eun, Baik-Lin, Hong, Y. S., and Lee, J. W. (2006). Usefulness of mod- ified $\mathrm{ambu}^{\circledR}$ in patients who need artificial ventilation, Korean Journal of Pediatrics, 49(11), pp. 1194-1201.

Hong, S. K. (2012). Mode of Ventilation, Journal of Surgical Critical Care, 2(2), pp. 39-41.

Kim, Y. S. (2019). Starting, maintaining and weaning of Mechanical ventilation, The Korean Journal of Medicine Spring Conference Papers, 96, pp. 200-203.

Korean Society of Anesthesiologists (KSA). (2020). Recommendations for COVID -19 suspected infection of patient anesthesia, KSA, pp. 1-3.

Park, J. (2018). Monitoring and interpretation of mechanical ventilator waveform in the neuro-intensive care unit, Journal of Neurocrit Care, 11(2), p. 64.

Son, D. W. (2012). New Modes of Ventilation for Neonates, Neonatal Medicine, 19(4), pp. 165-183. 